\title{
Sodomía y masculinidad en la ciudad de México (1821-1870)/
}

Sodomy and Masculinity in Mexico City (1821-1870)

\section{Alejandra Palafox Menegazzi \\ Universidad de Granada}

El artículo indaga en las construcciones socio-culturales que operaron dentro del dispositivo de control de la sexualidad en la capital mexicana, a través del análisis discursivo de expedientes judiciales relativos a casos de sodomía. Se exploran mecanismos de reproducción de las categorías dicotómicas de género, dentro de un sistema de dominación que, a lo largo del siglo XIX, sujetó tanto a hombres como a mujeres a través de una masculinidad prescriptiva.

Palabras ClaVE: Sodomía; Masculinidad; Independencia; Normativa; Violencia; Desigualdad.

This article explores, through the discursive analysis of sodomy's court records, the socio-cultural constructions that operated within the control device of sexuality in Mexico City. It also examines the mechanisms of reproduction of dichotomous gender categories within the context of a system of domination which, during the nineteenth century, put both men and women through a prescriptive masculinity doctrine.

KEYwORDS: Sodomy; Masculinity; Independence; Law, Violence, Inequality. 


\section{Introducción}

Las relaciones de género que imperaron en la heterogénea sociedad mexicana a lo largo del siglo XIX supusieron la implementación de un conjunto binario de reglas, tendentes a determinar las actitudes, valores e inclinaciones en las que hombres y mujeres, como tales, debían integrarse. La masculinidad prescriptiva, entendida como el referente ideal de comportamiento al que los hombres concretos debían sujetarse, pese a contener importantes matices en su interior, defendió un modelo de sexualidad basado en la posesión y el dominio femenino, así como, al menos en el ámbito formal, en la contención dentro de la esfera matrimonial.

Mediante el estudio de la regulación legal relativa al delito de sodomía y de los análisis temáticos de la misma por parte de tratadistas de Derecho y médicos legistas, se ha accedido a la lectura de diez procesos judiciales pertenecientes al periodo 1821 y $1870^{1}$ con el objetivo de observar la interactuación del ideal de masculinidad hegemónica en el tratamiento de uno de los comportamientos sexuales más condenados y responder a las siguientes preguntas: ¿Qué continuidades y rupturas se verificaron en las postrimerías coloniales en el tratamiento judicial del delito señalado? ¿Qué diferencias de género quedaron reflejadas en la construcción de la sodomía como desviación moral delictiva y en la práctica judicial relativa a la misma? ¿Cómo fue percibida por los actores sociales implicados en los juicios la violencia sexual ejercida por hombres contra individuos de su mismo género? ¿Por qué recibió un tratamiento diferenciado del otorgado a la violencia sexual ejercida sobre mujeres? Además del género, ¿qué otras variables determinaron la valoración judicial ante estos procesos?

Cabe advertir que la ausencia de clasificación del fondo documental consultado para la elaboración de este estudio no permite conocer la representatividad del número de procesos encontrados. Sin embargo, al haber examinado la mitad de dicho fondo de manera aleatoria, puede afirmarse que la proporción estimada de casos encontrados por año es uno por cada dos años.

La selección del marco temporal considerado en este artículo, que discurre desde la independencia mexicana de la metrópoli española en 1821

1 Pertenecientes al fondo «Tribunal Superior de Justicia del Distrito Federal» (TSJDF) del Archivo General de la Nación de México (AGNM). El material consultado, al encontrarse en proceso de organización y descripción, carece de foliación y número de expediente. 
hasta la promulgación en 1871 del Código Penal para el Distrito Federal y Territorio de la Baja California, ha respondido a la necesidad de ahondar en el tratamiento judicial de una tipología delictiva definida por la legislación colonial durante un periodo poco abordado por la historiografía actual. Los primeros cincuenta años de vida independiente constituyeron un puente entre dos épocas notablemente abordadas desde la academia: la época colonial y el Porfiriato. ${ }^{2}$ Se trata de un espacio temporal transitorio en el que se produjeron continuidades y rupturas con el periodo colonial, esenciales para comprender las dinámicas adquiridas durante el Porfiriato por una sexualidad masculina, entendida como una construcción socio-cultural. En concreto, al considerar los desarrollos teóricos formulados por Michel Foucault, ${ }^{3}$ el concepto de la sexualidad ha sido concebido y utilizado en este trabajo como un efectivo dispositivo de control, un engranaje histórico-cultural, elaborado como concepto a partir del siglo XVIII en Occidente, que a través de una acción, principalmente, discursiva, ha constituido un sistema de valores normativos sobre la conducta sexual.

\section{Precedentes, conceptualización y condena}

Hacer referencia al Tercer Concilio Provincial mexicano, celebrado en 1585, en relación al tratamiento de la sexualidad mexicana durante el siglo XIX puede parecer anacrónico. Sin embargo, a lo largo del periodo estudiado en este artículo la interrelación entre religión y norma, a pesar del monopolio judicial ostentado por las autoridades civiles ante los delitos de sodomía, impregnó la regulación de la sexualidad.

La implantación de las medidas aprobadas en Trento entre 1545 y 1563, incluyendo la normativa teológica sintetizada por Santo Tomás de Aquino en el siglo XIII, tuvo lugar en México a partir del concilio aludido. ${ }^{4}$ Tanto los preceptos aprobados durante el Tercer Concilio Provincial como el texto tomista gozaron de especial relevancia en el siglo XIX, ya que los primeros se mantuvieron vigentes en la archidiócesis de México

2 Para el desarrollo del tratamiento de sodomía y la homosexualidad en la sociedad colonial y durante el Porfiriato véase Barrón Gavito, 2010; Bracamonte, 2001; Buffington, 2001; De los Reyes, 2010; Garza Carvajal, 2000; Irwin, 2003; Monsiváis, 2001.

3 Foucault, 1998, 32, 62. Este autor desarrolla también el concepto de sexualidad como objeto de los mecanismos de control sobre los cuerpos. Al respecto, véase Foucault, 2003, 178, 216, 273.

4 Galván Rivera, 1859, 122. 
hasta $1896^{5}$ y el segundo llegó, incluso, a convertirse en la teología oficial de la Iglesia Católica. ${ }^{6}$

De acuerdo con lo expuesto en la Suma Teológica por Santo Tomás de Aquino, el placer coital era el mayor de los placeres humanos, entendidos como medios, inevitables, que acompañaban las operaciones requeridas para el desarrollo de la vida humana, como la reproducción. ${ }^{7}$ El goce venéreo debía siempre ir acompañado de la templanza con el objetivo de no caer en el vicio de la lujuria, consistente en «la búsqueda desordenada del placer». ${ }^{8}$ Entre las diversas especies de lujuria existentes, ordenadas jerárquicamente por su nivel de malicie, el llamado vicio contra la naturaleza, o contra natura, ocupó el puesto más elevado. Esta categoría debió su nombre al hecho de que en ella figuraron actos que se opusieron «al mismo orden natural del acto venéreo», es decir, a la procreación, al desperdiciar el semen producido en el acto sexual. ${ }^{9}$

Dentro de esta teoría, el varón representaba al único dador de vida después de Dios, al considerar que su semen era la semilla que permitía la generación de nuevos individuos mediante su introducción en la mujer, quien fungía como un necesario pero pasivo receptáculo en la labor reproductora. ${ }^{10} \mathrm{El}$ «vicio sodomítico», que dentro de esta taxonomía figuraba como el acto más grave después de la bestialidad, ${ }^{11}$ estaba definido como «el coito con el sexo no debido» y era más condenable cuando lo cometían dos hombres, por suponer una ofensa directa contra el orden natural creado por Dios. ${ }^{12}$

Hasta mediados del siglo XVIII, la Iglesia gozó en el virreinato de Nueva España de poder hegemónico y legitimidad en el control de los comportamientos privados o desarrollados dentro del ámbito familiar. ${ }^{13}$ Los procesos de delación, persecución y procesamiento de las personas acusadas de haber cometido sodomía estuvieron regulados por el fuero eclesiás-

5 El IV Concilio Provincial no contó con las ratificaciones real y pontificia necesarias, por lo que las medidas aprobadas en 1585 se mantuvieron vigentes hasta la celebración del V Concilio en 1896. Ibidem, 33.

6 Ortega Noriega, 1988, 19.

7 Ibidem, 27.

8 Ibidem, 30.

9 Cuestión 154, Artículo 11, en Aquino, 1994, 483.

10 Tomás y Valiente, 1990, 35.

11 Según Tomás de Aquino, la bestialidad era el «coito con una cosa de distinta especie». Aquino, 1994, 483.

12 Ibidem, 484.

13 Bracamonte, 2001, 395. 
tico con base en una legislación civil que retomaba los principios tomistas y que estuvo compuesta, principalmente, por los textos de Las Siete Partidas del Rey Don Alfonso el Sabio y las pragmáticas promulgadas por los Reyes Católicos y Felipe II recogidas en la Novísima Recopilación de las Leyes de España.

La conflictividad existente entre las autoridades civiles y las eclesiásticas por el aumento y el mantenimiento, respectivamente, del control sobre la población novohispana, se tradujo en la prohibición en 1746, por Real Cédula, de que los tribunales eclesiásticos emitiesen sentencia ante casos de delitos sexuales. ${ }^{14}$ De esta manera, el Tribunal del Santo Oficio tuvo que aceptar que las acusaciones de sodomía se formulasen o remitiesen a la Real Sala del Crimen de la capital del virreinato. Como afirma Marcela Suárez Escobar, esto implicó el cese de una importante red de delatores, de un sistema inquisitorial compuesto por curas, frailes y familiares de la Inquisición, un aparato centralizado y articulado en torno a instrumentos tales como la carga, la culpa, el miedo y el secreto. ${ }^{15}$ En consecuencia, como se desarrollará en este artículo, aparecieron nuevos y dinámicos mecanismos de control, así como individuos encargados del funcionamiento de una serie de engranajes tendentes a la construcción y reproducción de determinados patrones de género dentro de una sexualidad regulada por el poder civil que, sin embargo, siguió manteniendo elementos característicos de la teología imperante.

Tras la independencia formal de México de la metrópoli española, con la firma del acta de independencia el 28 de agosto de 1821, se puso un punto final a la historia del virreinato de la Nueva España y tuvo lugar el surgimiento de un nuevo estado, formalmente independiente y soberano. ${ }^{16}$ Hasta finales del siglo XIX, sin embargo, la inestabilidad política asoló el país: México contó con más de treinta presidentes en cincuenta años y vio cómo se sucedían formas de gobierno tan dispares como una monarquía constitucional, una república federal, una república centralista y una dictadura. ${ }^{17}$ Por otro lado, las continuas guerras internas, acompañadas de invasiones extranjeras y pérdidas territoriales, completaron un panorama complejo para el desarrollo de una reorganización normativa acorde con las tendencias jurídicas imperantes, favoreciendo así la permanencia de un Derecho privado de origen colonial.

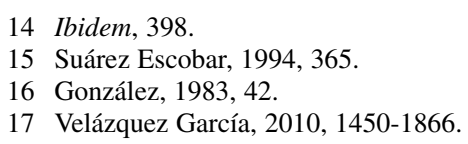


Según el artículo segundo del Reglamento Provisional Político del Imperio Mexicano, dictado el 10 de enero de 1822, se mantendrían vigentes aquellas leyes, órdenes y decretos que hubiesen sido promulgados antes del 24 de febrero de $1821^{18}$ y que no contradijesen los principios de la normativa expedida tras la independencia del país. ${ }^{19}$ A consecuencia de esta medida y de la ausencia de cuerpos jurídicos posteriores, la situación legal del México independiente estuvo caracterizada por un amplio pluralismo normativo y la vigencia del Derecho privado colonial, que operó como supletorio.

En relación con la sodomía, este concepto aludía en la época al «concúbito entre personas del mismo sexo o en vaso indebido». ${ }^{20}$ Sin embargo, como quedó recogido por los tratadistas de Derecho consultados, la ley sólo entendía por sodomía o pederastia ${ }^{21}$ el concúbito entre varones. Este hecho se debía a la interpretación de que el desperdicio de semen, al ser generador de vida, constituía un atentado contra Dios pero, al mismo tiempo, estaba relacionado con la concepción de una sexualidad femenina pasiva. Frente a una sexualidad masculina activa, poderosa y, en ocasiones, incontrolable, de acuerdo con el ideal de virilidad imperante, las mujeres fueron despojadas de su sexualidad, al ser vistas como seres carentes de deseos. ${ }^{22}$ Esta concepción promovió un control y una preocupación social menor ante posibles encuentros sexuales entre mujeres, lo que se tradujo en la masculinización de la sodomía.

La normativa colonial vigente estipulaba ante este delito la aplicación de severas penas caídas ya en desuso. Según el Fuero Juzgo las autoridades competentes debían ejecutar la castración como pena adecuada ante los delitos de sodomía, confiscando los bienes del reo y entregándoselos a su mujer e hijos, en caso de que los tuviera, permitiendo a su mujer que volviese a contraer matrimonio. El Fuero Real, por su parte, advertía que la castración debía hacerse en un espacio público, colgando al acusado de las piernas al tercer día de haber sido castrado hasta provocar su muerte.

La legislación recogida en Las Siete Partidas aminoró la crueldad de las leyes existentes, otorgando la pena capital a los condenados por sodo-

18 Fecha en la que fue aprobado el llamado «Plan de Iguala».

19 González, 1983, 46.

20 Escriche, 1876, 1544.

21 Los juristas Anastasio de la Pascua y Joaquín Escriche coinciden en equiparar semánticamente ambos términos.

22 Palafox Menegazzi, 2013, 25. Para una historia del «lesbianismo» durante el Porfiriato, véanse Irwin, 2004 y Núñez Becerra, 2008. 
mía sin especificar la manera de ejecutar la misma y eximiendo de ella a los menores de catorce años y a aquellas personas que hubiesen sido forzadas a cometer el delito. De acuerdo con el análisis realizado por Francisco Tomás y Valiente, este código seguía considerando la sodomía como un pecado contra natura, haciendo referencia a los pasajes bíblicos de Sodoma y Gomorra como si efectivamente hubiesen acaecido, para remarcar que la persona que cometiese sodomía atentaba contra la sociedad al provocar la ira de Dios. ${ }^{23}$

La Novísima Recopilación de las Leyes de España ${ }^{24}$ incluyó en lo referente al delito las pragmáticas emitidas por los Reyes Católicos en 1497 y por Felipe II en 1592. La primera establecía la muerte por quema en la hoguera y la confiscación de todos los bienes del acusado, además de permitir la aplicación del tormento ante un delito considerado «atrocísimo» y «nefando», por ser, respectivamente, equiparable a los delitos de herejía y lesa majestad, y no ser digno de nombrar. La segunda pragmática, pese a no incrementar las penas contempladas, permitía culpar a los acusados de sodomía aunque no existiesen testigos o las declaraciones de estos fuesen contradictorias.

Sin embargo, en relación con los mecanismos de control, sujeción y represión ante el delito de sodomía, a partir del siglo XVIII fue perceptible un notable relajamiento y una mayor permisividad ejercida desde las instancias civiles, debida, principalmente, al cambio de mentalidad acorde con los principios reformistas recogidos en la obra de teóricos como Cesare Beccaria. ${ }^{25}$ Principios como la humanización de las penas y la aplicación de castigos proporcionales a la gravedad del delito, así como una menor incidencia de la teología dentro del derecho fueron visibles en la actuación judicial de la capital virreinal y se mantuvieron durante el primer lustro de vida independiente del país. Al igual que lo acaecido en la metrópoli desde finales del siglo XVII, ${ }^{26}$ en Nueva España tuvo lugar una redefinición de actos delictivos como la sodomía, que dejaron de ser interpretados como una ofensa a Dios para convertirse en delitos contra la sociedad.

23 Tomás y Valiente, 1990, 41.

24 Novísima Recopilación de las Leyes de España, Leyes I y II, Título XII, Libro XXX.

25 El jurista milanés Cesare Beccaria formó parte de la llamada Escuela Clásica o Liberal del Derecho penal, corriente que responde a los postulados liberales y aboga por la proporcionalidad entre las penas y los delitos, la independencia del poder judicial y la superioridad del poder legislativo frente al ejecutivo y al judicial. Véase Speckman Guerra, 2002, 26.

26 Tomás y Valiente, 1990, 55. 
La secularización que tuvo lugar desde las últimas décadas de la época colonial en la capital novohispana supuso una progresiva conceptualización de la noción de delito, que fue, paulatinamente, sustituyendo a la de pecado en los discursos procesales. ${ }^{27}$ Desde los primeros años de independencia del país, el proceso de laicización y desplazamiento de la Iglesia en el control de los cuerpos y del ámbito privado, iniciado con las reformas borbónicas en el siglo XVIII, fue continuado dentro de un proyecto político de corte liberal, basado en la defensa de la tolerancia religiosa, la igualdad ante la ley, el individualismo y la ciudadanía. ${ }^{28}$

Sin embargo, este hecho no contradijo el sistema sexual que había imperado hasta el momento y permitió, en gran parte, el mantenimiento de una sexualidad articulada en torno a un conjunto de valores inspirado en la teología moral tomista, donde la sodomía siguió representando «la incontinencia más reprobada por las leyes y buenas costumbres como contraria a la naturaleza y de funestas consecuencias para la moralidad y conservación de la sociedad»..$^{29}$ Por otro lado, hasta las primeras décadas del siglo XIX, las acusaciones de sodomía formuladas ante las autoridades eclesiásticas, pese a que no fueron admitidas a trámite, se siguieron produciendo..$^{30}$ Este hecho se debió al desconocimiento del trasvase de competencias en materia judicial por parte de la población, incluyendo a miembros del bajo clero, así como al mantenimiento de una importante religiosidad institucional en la sociedad capitalina.

$\mathrm{Si}$ bien es cierto que las referencias a Dios en los procesos judiciales sobre sodomía fueron disminuyendo desde las postrimerías coloniales, las definiciones del concepto de sodomía como «pecado nefando» siguieron siendo visibles en los medios de comunicación y de difusión de las élites políticas e intelectuales de la ciudad a lo largo del siglo XIX. Las nociones de delito, pecado y atentado contra el orden natural, confluyeron en relación con un acto que siguió suponiendo un motivo de alarma social y escándalo. Un ejemplo de lo afirmado fue recogido el 1 de julio de 1823 en el periódico El Sol, donde se anunciaba la muerte de un joven de 18 años

27 Véase Bracamonte, 2001.

28 Las llamadas «Leyes de Reforma», impulsadas por los distintos gobiernos liberales desde mediados del siglo XIX, fueron máxima expresión de este proyecto.

29 Palabras expuestas por el fiscal Fonseca en 1843 en el caso por conato de sodomía contra Agustín Rojas. AGN, TSJDF, «Toca la causa contra Agustín Rojas por conato eficaz de sodomía», caja 180, México, 1843.

30 Bracamonte, 2001, 401. 
por sodomía. ${ }^{31}$ La víctima, según lo que supuestamente habría confesado a sus padres, fue violentado a consumar, dos años atrás, una relación carnal con otro hombre que le causó una inflamación del recto que fue «comunicándose sin duda a los demás intestinos, estómago, hígado, bazo, peritoneo», hasta acabar con su vida.

Ante este suceso, el periódico denunció la elevada frecuencia con la que esa «catástrofe»solía repetirse entre los jóvenes, particularmente en los colegios, como consecuencia de la «desmoralización de algunos de los alumnos» que se entregaban a «excesos tan horrorosos» y del descuido de los padres con respecto a la educación de sus hijos. Por último, la noticia concluía recordando la severidad con la que actuaban las «invariables» leyes de la naturaleza, dejando rara vez impune al «atrevido» que intentara trastornar su orden.

El hecho de que este caso de sodomía apareciera en el apartado de «Salud Pública», una sección poco frecuente en el periódico aludido, y no ya en otros, como el de «Tranquilidad Pública», respondió a la creciente relevancia que la medicina tuvo en el mantenimiento de un orden social y moral acorde con la normativa liberal en el siglo XIX. Pese a ello, sólo a partir de finales del siglo las inclinaciones homosexuales comenzaron a considerarse manifestaciones patológicas. ${ }^{32}$

En relación con los procesos y las condenas, a pesar de que los textos legales de época colonial antes citados no fueron derogados de manera explícita en el periodo aquí observado, algunas de las penas estipuladas en los mismos, como la confiscación de bienes, ${ }^{33}$ sí fueron abolidas en normas posteriores a la vez que otras cayeron en desuso, dentro de un Derecho consuetudinario ligado a postulados liberales defensores de una mayor proporcionalidad entre penas y delitos. ${ }^{34}$ Ya desde el siglo XVIII, tanto el número de acusaciones como la severidad en las sentencias por sodomía decrecieron considerablemente. Las condenas a muerte, tan frecuentes durante el siglo XVII ante este y otros delitos sexuales, ${ }^{35}$ fueron paulatinamente sustituidas por penas corporales como el encierro o los trabajos forzados.

31 Periódico El Sol, sección «Salud Pública», martes, 1 de julio de 1823, n. 17, 65.

32 Weeks, 2005, 204, 210 y Monsiváis, 2001, 304-309.

33 Las penas de azotes y confiscación de bienes habían sido ya abolidas por el decreto aprobado por las Cortes de Cádiz el 8 de septiembre de 1813, el artículo 147 del título V de la Constitución de 1824 y el artículo 179 de las Bases de 12 de junio de 1834.

34 Speckman Guerra, 2002, 26.

35 Bracamonte, 2001, 396. Para el estudio de las diferencias en las condenas por el delito de sodomía con base al estatus social de los acusados véase De los Reyes, 2010, 53-76. 
De acuerdo con lo expuesto por el médico forense Francisco Roa Bárcenas en 1869, ejemplos de condenas frecuentes ante estos casos solían ser el presidio de tres a seis años o la reclusión. ${ }^{36}$ Sin embargo, ante la sodomía, algunos juristas de la época no recomendaban la aplicación de penas concretas, dejando al arbitrio judicial su determinación. La ausencia de una reglamentación civil específica del mismo, según otros juristas como Anastasio de la Pascua, se debió a un silencio impuesto por el agravio que dicho acto «execrable» constituía para el pudor, lo que evidenciaba la permanencia de la caracterización de la sodomía como nefanda. ${ }^{37}$

Hasta la materialización de los proyectos de codificación civil y penal a finales del siglo XIX, se mantuvo, por tanto, una situación caracterizada por la pluralidad normativa y la caída en desuso de las penas coloniales, lo que derivó en una situación de vacío legal suplida por el predominio del Derecho común y las circunstancias específicas de cada delito a la hora de emitir sentencias frente a la ley escrita, mediante el ejercicio de una amplia discrecionalidad judicial..$^{38}$

Un ejemplo de lo expuesto puede observarse en la diversidad de las sentencias relativas a los once acusados por sodomía en los diez expedientes judiciales consultados. De los enjuiciados, cuatro fueron absueltos, dos fueron puestos en libertad tras pasar tres meses presos, uno fue condenado a cumplir cinco años de servicio en un hospital, dos a cuatro años en una casa de corrección y cuatro años de obras públicas, respectivamente, y otro a un año de presidio en Texas. ${ }^{39}$ En el caso contra el coronel Manuel Montoro, el acusado no recibió sentencia judicial por gozar de fuero militar. ${ }^{40}$

36 Roa Bárcenas, 1869, 419.

37 De la Pascua, 1835, 171 y Ortega Noriega, 1988, 32.

38 Speckman Guerra, 2007, 190.

39 En orden de enumeración: AGN, TSJDF, «Toca a la causa instruida en el Juzgado de lo criminal contra Julián Díaz y socio por sodomía», caja 400, México, 1865; AGN, TSJDF, «Toca a la acta instruida en el Juzgado 2o de lo criminal de México a Santiago López por sodomía», caja 387, México, 1864; AGN, TSJDF, «Toca a la causa instruida en el Juzgado 2o de lo criminal contra Juan Galicia por el conato de sodomía», caja 387, México, 1864; AGN, TSJDF, «Contra Mariano Jiménez por sodomía», caja 330, México, 1858; AGN, TSJDF, «Contra Juan Portillo por sodomía», caja 416, México, 1865; AGN, TSJDF, «Pascual González y Filomeno Sánchez por sodomía», caja 73, México, 1832; AGN, TSJDF, «Toca a la causa instruida en el Juzgado 3 de la criminal contra Fermín Alanis acusado de sodomía», caja 387, México, 1864; AGN, TSJDF, «Causa instruida por el juez 4. ${ }^{\circ}$ de lo criminal, lic. Manuel Flores Alatorre, contra Timoteo Vallejo y Floriano Mondragón», caja 330, México, 1858; y AGN, TSJDF, «Toca a la causa contra Agustín Rojas por conato eficaz de sodomía», caja 180, México, 1843.

40 AGN, TSJDF, «Testimonio de lo que resulta contra el S. Coronel D. Manuel Montoro, en la acusación que hizo a D. Santiago Castellanos», caja 130, México, 1838. 
TABLA 1

RELACIÓN DE ACUSADOS Y CONDENAS

\begin{tabular}{|c|c|c|c|}
\hline Nombre acusados & Profesión & $A \tilde{n} o$ & Sentencia \\
\hline $\begin{array}{l}\text { Pascual González } \\
\text { y Filomeno Sánchez }\end{array}$ & No consta & 1832 & $\begin{array}{l}\text { Puestos en libertad } \\
\text { tras dos meses en } \\
\text { prisión a la espera } \\
\text { de sentencia. }\end{array}$ \\
\hline Manuel Montoro & $\begin{array}{l}\text { Coronel del } \\
\text { Ejército }\end{array}$ & 1838 & $\begin{array}{l}\text { Caso entregado a la } \\
\text { justicia militar }\end{array}$ \\
\hline Agustín Rojas & No consta & 1843 & $\begin{array}{l}\text { Un año de trabajo en } \\
\text { obras públicas } \\
\text { en Texas }\end{array}$ \\
\hline Mariano Jiménez & $\begin{array}{l}\text { Vendedor de } \\
\text { carbón y café }\end{array}$ & 1858 & Libertad \\
\hline $\begin{array}{l}\text { Timoteo Vallejo y } \\
\text { Floriano Mondragón }\end{array}$ & Carpinteros & 1858 & $\begin{array}{l}\text { Cuatro años de } \\
\text { obras públicas } \\
\text { y cuatro años en } \\
\text { casa de corrección. }\end{array}$ \\
\hline Fermín Alanís & No consta & 1864 & $\begin{array}{l}\text { Cinco años de } \\
\text { servicio en un } \\
\text { hospital }\end{array}$ \\
\hline Santiago López & No consta & 1864 & Libertad \\
\hline Juan Galicia & No consta & 1864 & Libertad \\
\hline Juan Portillo & Carpintero & 1865 & $\begin{array}{l}\text { Libertad tras tres } \\
\text { meses en prisión } \\
\text { a la espera de } \\
\text { sentencia }\end{array}$ \\
\hline $\begin{array}{l}\text { Julián Díaz y Santos } \\
\text { Alvarado }\end{array}$ & $\begin{array}{l}\text { Cocinero y } \\
\text { labrador }\end{array}$ & 1865 & Libertad \\
\hline
\end{tabular}


Con la promulgación del Código Penal del Distrito Federal y Territorio de la Baja California, el 7 de diciembre de 1871, la sodomía dejó de estar tipificada como delito en la ciudad de México. Este hecho, sin embargo, no impidió que esta práctica continuase criminalizada al insertarse dentro de la amplia categoría de ultrajes a la moral pública o las buenas costumbres. A lo largo del siglo XIX, por tanto, el mantenimiento de concepciones normativas de origen medieval y la persistencia de vestigios teológicos dentro de las re-significaciones que giraron en torno al concepto de sodomía, derivaron en la categorización de esta práctica en la esfera de lo moral, es decir, dentro de los mismos parámetros maniqueos de «bien» $\mathrm{y}$ «mal» que habían reinado durante la interpretación de la sodomía como pecado. ${ }^{41}$

\section{Delación, interpretación y arbitrio}

A pesar de la pérdida de poder eclesiástico sobre la regulación de las actitudes y prácticas sexuales poblacionales y de la consiguiente ausencia de una importante red de delatores ${ }^{42}$ la comunidad como red de acusación y custodia de la moral pública y de las buenas costumbres siguió constituyendo, a lo largo del periodo estudiado, un instrumento de control al servicio del poder, en este caso, secular. Esta situación se produjo gracias al mantenimiento de una serie de vínculos comunitarios de actuación vecinal, unido a una notable confianza poblacional en las autoridades civiles como cuerpos encargados de vigilar, contener y sancionar desviaciones de la normativa sexual vigente, como la sodomía.

Por otro lado, el vacío normativo existente frente al delito de sodomía, promovió que el Derecho consuetudinario, las circunstancias de cada caso y la retórica tanto de la acusación como de la defensa, constituyeran elementos cruciales ante un amplio arbitrio judicial. Esta situación permitía que una misma ley recibiera interpretaciones completamente opuestas por parte de los juristas. El conocimiento de la normativa y su empleo de manera estratégica, haciendo uso de un lenguaje especializado, sirvieron como instrumentos claves en la persecución de un objetivo claro: impresionar a la autoridad judicial o derribar a la parte contraria aparentando una gran erudición.

41 «Delito contra el orden de las familias, la moral pública o las buenas costumbres», recogido en el Libro II, Tít. VI del Código Penal del Distrito Federal y Territorio de la Baja California.

42 Suárez Escobar, 1994, 365. 
El juicio por sodomía que el 8 de agosto de 1832 se inició contra Pascual González y Filomeno Sánchez ejemplifica lo afirmado. ${ }^{43}$ En este caso, la acusación fue realizada después de que, supuestamente, el joven Torres, de doce años, hubiera visto a los acusados en un cuarto con la puerta entrecerrada y «en actitud y disposición de cometer un delito». En atención a la declaración del muchacho y demás testigos, al observar el comportamiento «indecente de ambos reos», estos le reprendieron por estar espiando y el joven partió inmediatamente en búsqueda de un adulto. Al encontrar a Loarías y contarle lo sucedido, este acudió al lugar de los hechos, donde halló a González y Sánchez en una «situación que indicaba su inhonesta [sic] y criminal acción», por lo que fue a dar aviso al alcalde auxiliar Carabes, quien aprehendió a los sospechosos.

En atención a la declaración de Carabes, ninguno de los acusados negó lo acaecido: González, tras ser detenido, reconoció que estaba dispuesto a hacerlo y que ya lo había hecho con anterioridad. Sánchez, por su parte, tampoco negó haber cometido el delito, cuestionando al alcalde que «en caso de haberlo ejecutado, qué le habían de hacer». Llamados a declarar ante el juez de primera instancia, Pedro Galindo, tanto González como Sánchez negaron las acusaciones formuladas y, ante esta situación, el juez ordenó el 9 de octubre del mismo año la puesta en libertad de ambos, siempre que su sentencia fuese confirmada por la Tercera Sala de la Suprema Corte de Justicia. ${ }^{44}$

Tras dos meses en prisión, ambos reos tuvieron que aguardar la lectura del caso por parte del ministro fiscal Juan Bautista Morales y la decisión confirmatoria o revocatoria de la Tercera Sala. Morales, tras el estudio del expediente judicial remitido desde el tribunal inferior, basó su petición en la Novísima Recopilación de las Leyes de España, recordando el rigor con el que las leyes trataban a los reos de tal crimen y citando las pragmáticas dadas por los Reyes Católicos y Felipe II por las que se castigaba «con la pena capital hasta el conato». ${ }^{45} \mathrm{Al}$ haberse moderado el rigor de estas disposiciones por la práctica judicial, el fiscal, en atención a la pragmática sobre la Conmutación de las penas ordinarias de los delitos en la de servi-

43 AGN, TSJDF, «Pascual González y Filomeno Sánchez por sodomía», caja 73, México, 1832.

44 En el artículo 33 de la Ley de 14 de febrero de 1826, Bases para el reglamento de la Suprema Corte de Justicia, se establece que «en las causas criminales comunes no podrá haber menos de dos instancias, y habrá lugar a la tercera si la segunda sentencia no fuere conforme de toda conformidad con la primera» (en Poder Judicial de la Federación, 1985, 55).

45 Novísima Recopilación de las Leyes de España, Leyes I y II, Título XII, Libro XXX. 
cio de galeras, ${ }^{46}$ pidió a la Tercera Sala que los acusados fuesen sentenciados a seis años de trabajos en un presidio de Texas.

Ante la solicitud del fiscal, el abogado don Pedro Montes de Oca sostuvo firmemente la inocencia de los acusados y, en relación con la misma normativa citada por Morales, pidió a la Tercera Sala la confirmación de la sentencia del juez Galindo y la consiguiente puesta en libertad de sus defendidos. Según el abogado, como se recogía en la Pragmática dada por Felipe II en 1598, para poder probar el delito de sodomía debía haber «una prueba privilegiada»y «tres testigos mayores de toda excepción aunque singulares» o cuatro testigos de cualquier tipo, además de indicios que corroborasen lo afirmado por los testigos. ${ }^{47}$

Montes de Oca continuó su discurso de defensa estructurando el mismo con base a la normativa leal y las irregularidades observadas en el juicio frente a la misma, afirmando que:

Un muchacho menor de doce años y que a esta edad no sabe la doctrina cristiana y un acusador perjuro desmoralizado y vil, son la prueba de todo lo que hay del hecho que se imputa a mis defendidos $¿ y$ en ella podrá descansar un fallo judicial que condene a dos desgraciados? Ciertamente que no es de temer la ilustración e integridad de ese respetable tribunal, además que el testimonio de estos hombres es del todo inverosímil, pues no es creíble que con la puerta abierta y después de una reconvención, hubieran continuado en el mismo estado. ${ }^{48}$

Tras oír esta defensa, la Tercera Sala de la Suprema Corte de Justicia ordenó el 22 de diciembre confirmar la sentencia del juez inferior, poniendo en libertad a González y Sánchez, presos desde agosto del mismo año.

Este caso ilustra la situación de vacío normativo existente frente al delito de sodomía. El Derecho consuetudinario, las circunstancias de cada caso y la retórica tanto de la acusación como de la defensa, constituyeron elementos de una influencia crucial ante un amplio arbitrio judicial. Las mismas leyes, como se ha puesto de manifiesto, podían ser objeto de interpretaciones que llevasen a conclusiones completamente opuestas. El cono-

46 Novísima Recopilación de las Leyes de España, Ley II, Título XL, Libro XII: recoge la pragmática dada por Carlos I el 25 de noviembre de 1552 y por Felipe II en mayo de 1566, según la cual: en los delitos de fuerzas «y otros delitos semejantes o mayores» con excepción de aquellos tan graves que conviniese a la República diferir la ejecución de la justicia y siempre que las partes «querellosas» no fueran perjudicadas, las penas ordinarias debían ser conmutadas por la de servir en galeras.

47 Novísima Recopilación de las Leyes de España, Ley II, Título XXI, Libro XXX. 1832.

48 AGN, TSJDF, «Pascual González y Filomeno Sánchez por sodomía», caja 73, México, 
cimiento de la normativa formal, así como su empleo de manera estratégica, haciendo uso de un lenguaje especializado, sirvió como un instrumento clave en la persecución de un objetivo claro: impresionar a la autoridad judicial o derribar a la parte contraria aparentando una gran erudición.

La continua referencia a los códigos normativos en el ámbito jurídico formó parte de un proceso de «tecnificación de los procesos judiciales» originado con las reformas impulsadas por Carlos III en el siglo XVIII, que produjeron una sustitución de paradigmas en la valoración de las elites jurídicas. ${ }^{49}$ Tras la independencia de la metrópoli española, las autoridades políticas mexicanas mantuvieron su interés en fortalecer y dotar de una mayor eficacia a los instrumentos del Estado, incluyendo la administración y el poder judicial, por lo que el respeto de la ley y las reglas procesales se consolidaron como requisitos para estar bien valorado dentro del ámbito jurídico. Además, con la promulgación del decreto de gobierno dado por el general Antonio López de Santa-Anna en 1841, la referencia al marco legal vigente durante el desarrollo de los procesos quedó plasmada como requisito para poder formular y mandar ejecutar cualquier tipo de decisión judicial. $^{50}$

El proceso judicial descrito contuvo otros elementos interesantes desde el punto de vista de un proceso de secularización en desarrollo, que no rompió radicalmente con un pasado inmerso en la teología moral. Como se ha observado en el juicio por sodomía contra Pascual González y Filomeno Sánchez, la defensa de los acusados consideró que el testimonio de uno de los testigos no era válido por no conocer este «la doctrina cristiana» a causa de su juventud. Esta referencia permite contemplar cómo a mediados del siglo XIX la sodomía, pese a no estar regulada por las instituciones eclesiásticas, seguía considerándose una desviación ligada a un código de valores cristiano.

En otro caso, el tejedor Francisco de Paula Rentería, tras haber sufrido mientras dormía un supuesto acto de abuso sexual por parte de Mariano Jiménez, tampoco dudó en acudir a las autoridades civiles para denunciar el acto y acusar de sodomía a su responsable. ${ }^{51}$ Los hechos se dieron en julio de 1858, cuando Francisco Rentería y Domingo Ordóñez acudieron a Tlalpan de Xochimilco con el objetivo de vender rebozos. Al llegar la

49 Cárdenas Gutiérrez, 2006, 176.

50 López de Santa Anna, 1877, 37.

51 AGN, TSJDF, «Contra Mariano Jiménez por sodomía», caja 330, México, 1858. 
noche, ambos compañeros buscaron posada, encontrándola en una casa que el vecino Mariano Jiménez tenía en alquiler y donde solía dormir, además de vender café y carbón. A las nueve de la noche, Jiménez despertó a Rentería, que dormía sobre un poyete, invitándolo a compartir con él su petate, con el pretexto de que ahí estaría más cómodo. Al acostarse, como Rentería le daba la espalda, Jiménez le dijo que se volteara y este le contestó «que no podía por acostumbrar dormir sobre el brazo izquierdo». Tras quedarse dormido, Rentería despertó al sentir «alteración en el miembro que le manoseaba Jiménez» cuando advirtió que «la mano derecha la tenía puesta en el suyo». Inmediatamente, Rentería se levantó del petate, despertó a su compañero y, sin decirle por qué, salieron de la casa. Según el documento declaratorio de Domingo Ordóñez, al salir de la casa, en el portal encontraron casualmente al prefecto del lugar, al que Rentería se acercó y habló en secreto, contando al declarante lo ocurrido sólo en las instancias judiciales, donde le confesó que «Mariano Jiménez, que fue quien le dio posada, le tocó las partes».

La actitud de Francisco Rentería, según las declaraciones recogidas en el expediente, respondió, por un lado, al miedo y la vergüenza que le suscitó lo ocurrido. La posibilidad de que su propio compañero o cualquier vecino cercano, dudara de su integridad como hombre de recta conducta sexual explicaría la precaución de hablar en voz baja con el prefecto y comentar lo ocurrido sólo una vez hallados en las instancias judiciales. El poder infamatorio que los rumores acerca de un acto sodomítico ${ }^{52}$ podían tener era tal que, ante la situación descrita, Rentería actuó con sigilo y determinación. De esa manera, acudió a las autoridades para denunciar el hecho de forma inmediata, lo que reafirma el mantenimiento de la confianza en las autoridades civiles como instancias reguladoras del orden y la moral. En su defensa ante el juez José del Villar, ${ }^{53}$ Mariano Jiménez, hombre casado de cuarenta y cinco años, sostuvo que la acusación constituía una calumnia, afirmando que pese a que la noche indicada dio posada a los declarantes y les ofreció su petate, durmieron en sitios separados y con cobijas distintas.

52 El término «homosexual» surgió en el último tercio del siglo XIX en Europa y se empleó en México a partir de la década de 1920. Véase: Rodríguez, 2011, 1; Foucault, 1998, 56; e Irwin 1998, 41. En la actualidad, el término alude a relaciones sexuales entre personas del mismo sexo. Se ha empleado el término sodomítico por considerarlo más acorde con la época tratada.

53 Juez del Partido de Tlalpan. 
Ante los hechos descritos, al no haberse consumado el acto sodomítico y en atención a lo recogido en la «Ley de vagos, heridores, homicidas y ladrones» de 1857, el juez ordenó la puesta en libertad de Jiménez. Según lo redactado en la citada ley, la simple intención de cometer un delito, así como el abandono espontáneo por parte del acusado de los actos preparatorios para llevar a cabo el mismo, no merecía pena. No es posible saber si el denunciante, en mayor medida, pretendía con su actuación que el supuesto delincuente fuera castigado o que su propio crédito y honor fueran salvaguardados. Lo que sí parece obvio es que su desconocimiento de la normativa legal impidió que se cumpliera el primer objetivo.

\section{La fuerza como agravante: la exclusividad femenina de la violación}

Si un acto sodomítico se llevaba a cabo mediante el empleo de violencia, las autoridades solían castigar el mismo con mayor severidad. Sin embargo, tanto médicos como juristas, a lo largo del siglo XIX, interpretaron que la violación era un delito que podía cometerse sólo contra mujeres. Las construcciones simbólicas existentes en torno a la virginidad y el honor femeninos promovieron distintas lecturas y reacciones ante los delitos de fuerza carnal sobre mujeres y sodomía con violencia.

A diferencia de lo observado en el caso contra Mariano Jiménez, antes descrito, el acusado Agustín Rojas, pese a no haber consumado el acto sodomítico contra el impúber Sebastián Tapia, fue condenado en 1843 a un año de trabajo en obras públicas. ${ }^{54}$ La causa de esta sentencia fue que, según lo expuesto ante el juez por los testigos, Rojas no logró forzar a Tapia porque los gritos de este alarmaron a varias personas que acudieron en su auxilio. Al considerar que el delito no se llevó a cabo gracias a la intervención de los vecinos, así como la fuerza con la que Rojas trató de que Tapia «accediera a sus deseos», tanto el fiscal José Urbano Fonseca como la Tercera Sala del Superior Tribunal de Justicia coincidieron en que el detenido fuese condenado a un año de obras públicas.

En relación con los códigos legales vigentes, a excepción de Las Siete Partidas, ninguno de los textos reguladores del delito de sodomía hacía referencia a la voluntad de los implicados en el mismo. Cometía sodomía

54 AGN, TSJDF, «Toca la causa contra Agustín Rojas por conato eficaz de sodomía», caja 180, México, 1843. 
aquel que hubiese contraído relaciones sexuales con otro hombre independientemente de que en la acción hubiese mediado cualquier tipo de violencia o coacción. El rasgo definitorio del acto, a lo largo del siglo XIX, siguió estando representado por el atentado que contra el orden natural y la sociedad suponía la emisión de semen fuera del acto reproductivo, constituyendo la fuerza un agravante en su tratamiento por parte de la justicia.

En ocasiones, a pesar de la existencia de indicios físicos, la comisión del delito sodomítico no fue condenada por las autoridades judiciales competentes al considerar que las pruebas no eran concluyentes. Así, la tercera sala del Supremo Tribunal de Justicia del Imperio ${ }^{55}$ confirmó en 1865 la sentencia del juez de primera instancia D. Agustín Fernández, por la que Julián Díaz y Santos Alvarado, de cuarenta y veinticinco años respectivamente, fueron absueltos de la acusación del delito de sodomía perpetrado contra el joven de 16 años, Manuel Aldana. ${ }^{56}$ En atención a la declaración de este, mientras se encontraba en la casa de Díaz en el pueblo de San Cristóbal de Ecatepec, ambos acusados «por la fuerza lo usaron carnalmente». El juez Fernández, tras escuchar las declaraciones de Díaz y Alvarado, quienes no reconocieron el delito, ordenó que dos facultativos reconocieran tanto a la supuesta víctima como a los acusados. Tras efectuar las exploraciones pertinentes, los médicos encargados afirmaron que el joven Aldana tenía síntomas de «sífilis» en el recto mientras que Díaz y Santos los tenían en el «miembro viril». ${ }^{57}$ Estos resultados, junto con la declaración de un testigo del pueblo que afirmó que había oído a una mujer desconocida que designaba a Díaz con el apodo de «joto», ${ }^{58}$ fueron los únicos indicios de la comisión del delito. Tanto el juez inferior como el Supremo Tribunal de Justicia no consideraron que existieran pruebas suficientes para culpar a los acusados y, por este motivo, haciendo alusión a Las Siete Partidas ${ }^{59}$ ordenaron la puesta en libertad de ambos.

55 Hace referencia al Imperio de Maximiliano I quien, tras la ocupación francesa en México, gobernó el país entre 1864 y 1867.

56 AGN, TSJDF, «Toca a la causa instruida en el Juzgado de lo criminal contra Julián Díaz y socio por sodomía», caja 400, México, 1865.

57 La ausencia de referencias en los tratados médico-legistas escritos en México de la época sobre el protocolo seguido en las exploraciones médicas ante supuestos casos de sodomía dificulta el conocimiento de los mismos. Para el estudio de las referencias teóricas de estos exámenes en España o Francia, véase: Bonaventure, 1847, 159-160 y Tardieu, 1863, 114-167.

58 Este calificativo hace referencia, de forma despectiva y grosera, a hombres con inclinaciones sexuales homosexuales.

59 La Ley XII, Título XIV, Partida III sostenía que los pleitos debían ser probados con «pruebas claras como la luz en que no venga ninguna duda». Véase Nepomuceno Rodríguez, 1852, 97. 
De acuerdo con lo expuesto por el médico forense Francisco Roa Bárcena, la violación estaba tipificada como un delito consistente en la unión verificada por la fuerza entre un raptor y una mujer robada por este. ${ }^{60}$ Esta definición coincidía con la recogida por los tratadistas de Derecho más consultados de la época, como Joaquín Escriche, quien definió el delito de violación como «la violencia que se hace a una mujer para abusar de ella contra su voluntad». ${ }^{61} \mathrm{~A}$ diferencia del estupro, ${ }^{62}$ que se consideraba ejercido sólo sobre mujeres doncellas, viudas honestas, mujeres casadas o religiosas, una violación sucedía cuando un hombre forzaba a cualquier tipo de mujer.

Entre las diferentes definiciones de «estupro» que convivieron en el siglo XIX, la que predominó en las prácticas judiciales capitalinas fue la perteneciente al ámbito de la teología moral, basada en el «primer acceso que se tiene, por la fuerza o no, a una doncella». ${ }^{63}$ Los discursos de las élites judiciales de la ciudad de México evidenciaron que la virginidad representaba el eje vertebrador de la honradez de una mujer soltera, así como un elemento garante de su acceso a un buen matrimonio.

Por estos motivos, la valoración por parte de las autoridades médicas y judiciales de los daños corporales y morales de una violación femenina, residió en la castidad previa de la supuesta víctima. ${ }^{64}$ En contraposición, el hecho de que un hombre fuese forzado a mantener un encuentro sexual con otro hombre no se consideraba violación sino que seguía estando tipificado dentro del propio delito de sodomía. Tanto el forzador como la persona forzada habrían sido partícipes, según la concepción vigente, de un acto sodomítico.

De los diez expedientes sobre sodomía analizados, en tres casos figuraron órdenes judiciales para realizar exámenes médicos a los supuestos implicados en dicho delito para verificar el mismo. En comparación con los exámenes ordenados ante casos de delitos sexuales cometidos contra

60 Roa Bárcenas, 1869, 414-415.

61 Escriche, 1876, 153.

62 Ley I, Titulo XIX, Partida VII.

63 Escriche, 1876, 653.

64 Esta afirmación está sustentada en el análisis de los tratados de Derecho citados, además de en la lectura de cincuenta y cinco expedientes judiciales relativos a casos de estupro y violación pertenecientes al fondo documental TSJDF del AGNM. Los resultados de este estudio fueron expuestos bajo el título «Jueces, médicos y parteras: la regulación formal de la virginidad femenina en la ciudad de México (1821-1870)» en el I Coloquio Nacional de Estudios de Género en Humanidades, celebrado en la Facultad de Filosofía y Letras de la Universidad Autónoma de Tlaxcala. 
mujeres, la proporción fue ligeramente inferior. De cincuenta y cinco expedientes analizados sobre estupro y forzamiento en mujeres, los exámenes médicos se ordenaron como método probatorio en veintiuno, es decir en el $38,2 \%$ de los casos frente a un 27,2\% de los casos de sodomía ${ }^{65}$.

En el proceso contra Fermín Alanís, acusado de haberse «prestado» a que hicieran «uso de su cuerpo», ${ }^{66}$ los facultativos confirmaron la comisión del delito. Este hecho, unido a la confesión del reo y las declaraciones de los testigos, sirvió para que Alanís fuera condenado a cinco años de servicio en un hospital. Sin embargo, en los dos casos de forzamiento ejercidos sobre hombres en los que los exámenes fueron ordenados, a pesar de que los resultados ofrecidos por los facultativos competentes constataron indicios de penetración anal, los supuestos responsables fueron puestos en libertad. Las pruebas médicas realizadas en los casos en los que la sodomía se había ejercido con violencia, no fueron reconocidas, por tanto, como elementos probatorios del delito y gozaron de una menor consideración judicial frente a las declaraciones de testigos o a las referencias a la normativa legal por parte de abogados y fiscales.

\section{La sodomía como feminización}

Ser varón y mantener relaciones sexuales con otro hombre era un acto de por sí infamante. Sin embargo, dentro de este mismo acto, el hecho de ser penetrado suponía un mayor desprestigio social, por la asociación directa de este hecho con un comportamiento sexual femenino.

De esta manera, el joven de catorce años, José Vidal, según el testimonio de un familiar, habría sido «usado $»^{67}$ a la fuerza por Juan Portillo, carpintero de dieciocho años de edad, quien fue arrestado y conducido a la ciudad de México ante el juez don Agustín Fernández, el 12 de marzo de $1865 .^{68}$

De acuerdo con lo declarado por José Vidal, el acusado se encontraba sentado frente a una garita a la que Vidal accedió para coger unos caballos.

65 Los expedientes sobre violación y estupro aludidos pertenecen también al fondo documental TSJDF del AGNM.

66 AGN, TSJDF, 1864, caja 387, «Toca a la causa instruida en el Juzgado 3 de la criminal contra Fermín Alanís acusado de sodomía».

67 Como se explicará más adelante, el verbo «usar» se empleaba comúnmente para hacer referencia a tener relaciones sexuales con una mujer.

68 AGN, TSJDF, «Contra Juan Portillo por sodomía», caja 416, México, 1865. 
Al ver al joven, «lo jaló de la mano, lo metió en un cuarto vacío» y, una vez dentro, «le quitó a fuerza los calzones y recargándolo contra la pared le metió el miembro en el ano». Después, «lo quiso acostar boca abajo en el suelo y como el exponente empezó a dar gritos, el desconocido con una navaja de afeitar le amenazó diciéndole que si no se dejaba lo mataba». Tras terminar la agresión, Portillo ordenó al joven que saliera del cuarto, advirtiéndole de que si lo hacía llorando le metería «la navaja por la espalda».

Aterrado, José Vidal corrió a su casa y le contó lo ocurrido a su madre, María Anselma, quien examinó su cuerpo y pudo observar que «arrojaba sangre». Ambos, junto con su tío, Juan Alvarado y el compadre ${ }^{69}$ de este, Refugio Colín, se dirigieron al lugar de los hechos en busca del desconocido, a quien encontraron en el camino de vuelta. Tras una breve persecución y, gracias a la colaboración del guardia José María Sánchez, el sospechoso fue detenido. Portillo, en su defensa ante el juez, declaró que la acusación era falsa. Durante el careo ordenado por el juez entre José Vidal y Juan Portillo, Vidal sostuvo «enérgicamente» que Portillo fue quien lo forzó y ambos reafirmaron lo expuesto en sus respectivas declaraciones.

Tras interrogar a los implicados en el delito y la persecución, el juez ordenó a los facultativos de la cárcel José Galindo y Fernando Castro Hoyos realizar un reconocimiento médico a José Vidal Ángelos, del que observaron que presentaba «en el ano hacia su parte interior y lateral izquierda dos "soluciones" de continuidad de cerca de un centímetro cada una, rojas con signos de inflamación», por lo que concluyeron que el joven había «sufrido la introducción de un cuerpo extraño duro y forzadamente».

A pesar de los resultados del examen médico y de los antecedentes penales que Portillo tenía por haber herido a otro hombre en 1864, de acuerdo con lo expuesto por Miguel Madrid, abogado de pobres adjudicado al acusado, con referencia a la normativa recogida en Las Siete Partidas, ordenó poner a este en libertad bajo fianza y envió el caso al Superior Tribunal de Justicia del Imperio para su revisión. ${ }^{70}$ Como expuso Madrid en su defensa, el delito estaba comprobado por la declaración de los facultativos pero lo que no había podido demostrarse era que Portillo fuese el

69 La relación de compadrazgo consistía en el vínculo establecido entre los padres y los padrinos de su hijo.

70 En su defensa, el abogado hizo referencia concretamente a la ya citada Ley XII, Título XIV, Partida III y a la Ley XXVI, Título I, Partida VII, en la que se afirmaba que si las pruebas que fuesen dadas contra el acusado atestiguasen claramente el yerro sobre el que fue hecha la acusación y el acusado fuese hombre de buena fama, debía ser puesto en libertad. 
responsable del mismo ya que en contra de este sólo figuraba la palabra de José Vidal, por lo que debía ser absuelto del cargo.

Al comparar la ejecución de las exploraciones médicas realizadas en los procesos de sodomía analizados con las recogidas en expedientes por estupro o violación femenina, ${ }^{71}$ se ha podido observar cómo los jueces competentes ordenaron los reconocimientos en estos últimos casos para determinar si las supuestas víctimas eran vírgenes antes del acto juzgado o si seguían siéndolo después de este pero no para verificar si habían sido forzadas. Los exámenes no perseguían encontrar lesiones o inflamaciones que demostraran un forzamiento sino comprobar si se había producido una «desfloración». Las causas de esta situación fueron, por tanto, de índole genérico-social más que médico-científicas y estuvieron directamente relacionadas con la supremacía del valor de la virginidad en el ideal de feminidad imperante, así como con el papel secundario jugado por la violencia ejercida sobre una mujer.

La ofensa que el atentado contra la virginidad de una doncella suponía, recaía no sólo en la mujer que lo sufría, sino, principalmente, en los miembros varones de su familia. Los padres, maridos o hermanos de la víctima eran, por tanto, los sujetos cuyo honor quedaba dañado tras la pérdida de la honra femenina. Al ser mayor el número de personas deshonradas mediante el estupro de una mujer que a través de la violación de un hombre, cabe pensar que los esfuerzos para redimir del agravio causado fueran mayores en el primer caso.

Como ya se ha referido, los daños que una violación causaba a una mujer, de acuerdo con las declaraciones de las élites médicas y judiciales de la época, residían, especialmente, en la pérdida de su condición de donce1la. ${ }^{72}$ Esta pérdida, si se efectuaba fuera del matrimonio, ya fuese de manera violenta, coaccionada o voluntaria, muy probablemente, causaría la depravación de la supuesta víctima en el futuro, quien caería en la mala vida y la prostitución. ${ }^{73}$ En contraposición, los daños morales sufridos por un varón

71 Entre los varios procesos consultados pueden citarse: AGNM, TSJDF, «Toca la causa contra José María Jiménez por estupro inmaturo», caja 131, México, 1838; AGNM, TSJDF, «José Trejo. Forzamiento», caja 217, México, 1845; AGNM, TSJDF, «Contra Ramón García por estupro de María Cárdena», caja 491, México, 1870 y AGNM, TSJDF, «Contra Juan Rivera por rapto y estupro», caja 491, México, 1870.

72 Los procesos analizados no muestran una valoración, por parte de las autoridades encargadas de dirimir las causas judiciales, del daño moral que una mujer violada podía sufrir, al margen de la pérdida de su honradez.

73 AGNM, TSJDF, «Toca la causa contra José María Jiménez por estupro inmaturo», caja 131, México, 1838. 
forzado, a pesar de su gravedad, no debían obstaculizar su desarrollo futuro. Estos residían en la feminización que suponía el sufrir una agresión de este tipo: una humillación que atentaba contra el honor de la persona violentada pero que no impediría poder reorientar la propia vida hacia un camino correcto, dentro de los parámetros imperantes, formar una familia y tener un trabajo honrado que permitiera vivir en unas buenas condiciones.

De acuerdo con el sociólogo Pierre Bordieu, en diversas culturas y tiempos históricos, la penetración entre varones estuvo vinculada a unas relaciones de poder y dominación en donde la persona penetrada sufría una humillación al estar el tratamiento recibido destinado a las mujeres. ${ }^{74} \mathrm{El}$ daño causado, en este caso, era irreparable y el encierro o castigo del responsable tenía como objetivo no ya un resarcimiento del mismo mediante la obligación de casarse o dotar a la víctima, como en el caso del delito de estupro, sino la protección de la sociedad ante personas capaces de cometer tan terrible acto.

La asociación de lo femenino con lo débil, lo pasivo, lo dependiente y lo irracional en los discursos emanados desde las instancias de poder a lo largo del siglo XIX, se constituyó mediante una oposición ante un modelo de masculinidad forjado en torno a la virilidad, el valor, la valentía y la razón. Una violación sufrida por un hombre, constituía una humillación relacionada, por tanto, con una asociación con la feminidad mediante la equiparación de su cuerpo con el cuerpo de las mujeres. La corporalidad sexual femenina a lo largo del periodo estudiado estuvo caracterizada, de acuerdo con los documentos médicos y jurídicos de la época, por una enajenación basada en la expropiación y la cosificación discursiva. De esta manera, en el proceso de sodomía con forzamiento sobre el joven José Vidal, descrito con anterioridad, según la declaración formulada por Refugio Colín, familiar de Vidal, este fue «usado» por Juan Portillo. El empleo de este término, no fue casual: «hacer uso» de una persona significaba «penetrarla», con violencia o sin ella. Tanto mujeres como hombres, al referir ante las autoridades judiciales que habían tenido una relación sexual, sostenían con normalidad que «habían sido usadas» o que «habían hecho uso», respectivamente. Sin embargo, la elección de este concepto en la declaración de Refugio Colín, contuvo una connotación negativa orientada a denunciar ante las autoridades el crimen ocurrido mediante la asociación de lo acaecido con funciones pasivas propias del cuerpo femenino.

74 Bourdieu, 2000, 40-41. 
El uso del calificativo $\left\langle\right.$ joto» ${ }^{75}$ y la asociación de un comportamiento afeminado con la comisión del delito de «sodomía» ${ }^{76}$ supusieron, por otro lado, la existencia de una identidad «sodomita» concreta. Si bien es cierto que en la literatura decimonónica el personaje del «joto» mexicano comenzó a definirse en torno a un comportamiento social más que a una práctica sexual, ${ }^{77}$ la relación entre ambos estuvo muy presente en los discursos de la época y creó una caracterización dentro del imaginario social previa a la elaboración del «homosexual» como personaje definido por sus inclinaciones naturales.

La relación entre lo femenino y lo sodomítico estuvo inserta dentro de una perspectiva que comenzaba a asociar las prácticas sexuales entre varones a una síntesis «enfermiza y peligrosa» ligada a un desorden que podía conducir al caos social. ${ }^{78}$ Esta especie de identidad simbiótica, sin embargo, no estuvo presente en todos los casos de sodomía consultados.

Por otro lado, pese a que el rol pasivo durante el acto sexual entre varones pudo haber sufrido un mayor estigma social por su directa asociación con el papel sexual ligado a la feminidad, en los documentos consultados aparecen hombres acusados de violación sodomítica cuya masculinidad fue también debatida al haber transgredido las reglas de la misma con su comportamiento. Sin embargo, en otras ocasiones, la virilidad de quienes fueron acusados de sodomizar a otros hombres no fue cuestionada y su comportamiento, como se verá a continuación, no apareció asociado a la feminidad.

\section{La desigualdad social en la práctica judicial}

La permanencia de los fueros y privilegios de determinados sectores durante la primera mitad del siglo XIX, así como las desigualdades originadas por la falta de poder adquisitivo de los implicados, repercutieron notablemente en el tratamiento judicial de los casos de sodomía analizados

75 AGN, TSJDF, «Toca a la causa instruida en el Juzgado de lo criminal contra Julián Díaz y socio por sodomía», caja 400, 1865.

76 El testigo D. Miguel Malo en el caso contra Juan Portillo, sobre la conducta del acusado afirmó que no había observado en él «ningún indicio ni maneras afeminadas aparte de tener hermanos pequeños y de haber tratado a los niños del declarante sin que le hubiera notado con ellos actos sospechosos». AGN, TSJDF, «Contra Juan Portillo por sodomía», caja 416, México, 1865.

77 Rodríguez, 2011, 3.

78 Ibidem, 19. 
y supusieron un lastre importante para la implantación de un proyecto liberal defensor de la supremacía de la sociedad civil en la capital mexicana.

En agosto de 1837 el juez Tamayo pidió a la Comandancia General de México la aprensión del coronel Manuel Montoro, acusado de los delitos de lenocinio y sodomía. ${ }^{79}$ De acuerdo a las informaciones aportadas por cinco testigos, Montoro, además de cohabitar con «un indio» que servía en su casa, ${ }^{80}$ solía acostarse con hombres a los que seducía a cambio de ofrecerles tener relaciones sexuales con su mujer, Guadalupe Cortés. Frente a la resistencia mostrada por algunos individuos, Montoro, haciendo uso de su poder, podía llegar a manosear o, incluso, a tratar de forzar a sus víctimas.

En función de lo sostenido por María Antonia Colín, una de los testigos, Montoro llevaba hombres a su propia esposa «a la cama para que con ella cohabitaran prestándose estos antes con él», siendo esta «la única paga que les exigía». Lo afirmado, según la testigo, era tan público y notorio, que podía ser acreditado tanto por, al menos, seis o siete miembros de la Comandancia de Matamoros, como por su marido, Santiago Castellanos y su compañero Herrera Esteva. Los dos últimos, teóricamente, rechazaron «prestarse con» Montoro, quien, además, había convencido a un indio llamado Mariano de perpetrar el crimen de sodomía a cambio de dinero.

La masculinidad de Montoro no apareció cuestionada en ninguna de las declaraciones recogidas en su contra durante el proceso judicial. $\mathrm{Su}$ comportamiento fue rechazado y los delitos cometidos fueron calificados como monstruosos y atroces pero Montoro no fue tachado de afeminado.

El acusado recibió en las declaraciones un tratamiento de «señor», seguido en ocasiones del de «coronel» y fue descrito como un militar violento que trataba de servirse de su rango, socialmente elevado, para perpetrar sus delitos. Cabe advertir que a lo largo del siglo XIX, convivieron dos estereotipos de masculinidad imperantes: uno, basado en la fuerza, la violencia, la inestabilidad y una sexualidad desbocada y otro definido por una actitud más moderada, ligada al trabajo y la fidelidad conyugal. ${ }^{81}$ A pesar de que las relaciones sexuales entre hombres contradijesen ambos estereotipos, paradójicamente, el rango militar adquirido por Montoro permitió

79 AGN, TSJDF, «Testimonio de lo que resulta contra el S. Coronel D. Manuel Montoro, en la acusación que hizo a D. Santiago Castellanos», caja 130, México, 1838.

80 A pesar de la eliminación formal de las desigualdades raciales frente a la ley, el calificativo de «indio» siguió utilizándose en la época para hacer referencia a la otredad indígena. Véase Ferrer 1998, 173.

81 Miranda Guerrero, 1998, 207-247. 
que este siguiese gozando de una virilidad, es decir, de una forma incuestionable de ser varón. Este poder, por otro lado, permitió, incluso, que el acusado fuese eximido de ser juzgado por la justicia civil, siendo remitido a la justicia militar por orden expresa del comandante general de México, Melchor Álvarez.

La permanencia del fuero militar constituyó una de las imágenes de la desigualdad de los ciudadanos ante el sistema judicial de la capital mexicana durante la primera mitad del siglo XIX. ${ }^{82}$ Hasta su abolición con la Constitución liberal de 1857, los militares gozaron de una situación de privilegio que les permitía escapar de la justicia ordinaria. De acuerdo con lo recogido en las leyes, ${ }^{83}$ los jueces militares debían conocer todas las causas civiles y criminales en las que fueran demandados los individuos del Ejército, permitiendo una situación de auténtico privilegio.

Como sostuvo el liberal Lorenzo Zavala en 1828, junto con los eclesiásticos, los militares eran seres privilegiados que pertenecían «a otra esfera», no conocían los deberes de los ciudadanos simples y se reputaban como «una clase superior a los demás». ${ }^{84}$

En los diez procesos analizados para la realización de este trabajo, las personas imputadas en los delitos, con excepción del coronel Montoro, pertenecieron a estratos socio-económicos populares. ${ }^{85}$ Esta situación puede responder al hecho de que las elites dispusieran de mayores medios para impedir que sus delitos trascendieran del ámbito privado o evadir condenas judiciales. Si se considera, además, la vigencia en la época de leyes especiales, como el fuero militar, puede afirmarse que el sistema judicial, en su función de instrumento controlador y represor de los comportamientos sexuales entre hombres, actuó en especial sobre los sectores poblacionales más desfavorecidos.

Como ya se ha comentado, en el proceso descrito contra Juan Portillo, el juez de primera instancia, Agustín Fernández, ordenó su libertad bajo

82 La exención de los miembros del Ejército de ser juzgados por la justicia civil ante casos de delitos penales quedó abolida por el artículo 13 de la Constitución Federal de los Estados Unidos Mexicanos en 1857.

83 Decreto del 9 de febrero de 1793 y Real Orden de 5 de noviembre de 1817. La Constitución de 1824, en su artículo 156, ratificó la vigencia de estas leyes. En 1842, el Soberano Congreso Constituyente trató de abolir estos privilegios pero su restablecimiento por decreto el 12 de octubre de 1842 retrasó su supresión hasta 1857. Véase: Reyes Heroles, 1974, 15.

84 Reyes Heroles, 1974, 8.

85 Pese a que sólo se contienen datos acerca del oficio desempeñado por seis de los acusados, la ausencia del distintivo de «don» para el resto confirma lo afirmado. 
fianza, al considerar que no existían pruebas que acreditasen su culpa. Tras la revisión del caso, el Superior Tribunal de Justicia ordenó que volviese al tribunal de origen para que se llevase a cabo la interrogación de testigos que acreditasen el lugar donde se encontraban el acusado y el demandante en el momento en el que se cometió el delito así como la buena conducta de ambos.

La obtención del primer objetivo no fue posible ya que en el momento en el que se produjo la supuesta agresión, Portillo y Vidal se encontraban a solas. La buena conducta de ambos, sin embargo, fue fácilmente demostrable. En relación con Portillo, las declaraciones de los testigos presentados por él mismo operaron como piedra angular en la resolución del caso. Con excepción del comerciante Ignacio Malo, quien sostuvo no conocer lo suficiente a Portillo, el resto de testigos coincidieron en que su conducta era correcta, siendo este un hombre honrado al que no se le apreciaba el «vicio de la sodomía». ${ }^{86}$

Tras examinar las declaraciones de los testigos y acreditar su buena fama, el 11 de diciembre de 1865 el Superior Tribunal de Justicia decidió confirmar la sentencia del juez Fernández y poner en libertad a Portillo, quien llevaba preso nueve meses. En este caso, por tanto, se cumplió la normativa recogida en Las Siete Partidas ${ }^{87}$ según la cual el acusado debía ser puesto en libertad siempre que fuese un «hombre de buena fama» y las autoridades judiciales no pudiesen probar su culpabilidad.

La desigualdad entre las dos partes enfrentadas en el juicio estuvo muy presente desde el momento en que la familia de José Vidal rechazó constituirse como parte acusadora en el mismo. Tanto la madre del joven, María Anselma, como Juan Alvarado y Refugio Colín, dejaron el caso en manos de la «justicia», a la que pidieron que ejerciera su acción «con energía por tratarse de un delito horroroso y atroz» ${ }^{88} \mathrm{La}$ decisión tomada por la familia, motivada seguramente por la falta de recursos económicos suficientes y el temor causado por el desconocimiento ante el funcionamiento de las instancias judiciales, supuso la ausencia de un abogado defensor de la acusación y, por ende, del respaldo de una persona que hubiese incrementado las posibilidades de condenar a Portillo al conocer las estrategias procesales de lucha ofrecidas por el complejo ensamble normativo vigente.

86 AGN, TSJDF, «Contra Juan Portillo por sodomía», caja 416, México, 1865.

87 Ley XXVI, Título I, Partida VII.

88 AGN, TSJDF, «Contra Juan Portillo por sodomía», caja 416, México, 1865. 
Como se hallaba recogido en la Novísima Recopilación de la Leyes de España ${ }^{89}$ la parte acusadora en un juicio estaba obligada a probar la comisión del delito por lo que, en la mayor parte de los casos, en vez de denunciar formalmente, los interesados, en secreto, solían avisar al juez de las circunstancias pertinentes, con el fin de que se procediese de oficio contra el detenido.${ }^{90}$ Cabe recordar, por otro lado, que, en caso de no poder demostrar la acusación, la parte demandante en el juicio podía ser acusada del delito de calumnia y verse constreñida a indemnizar económicamente a la persona ofendida. ${ }^{91}$

Esta situación, ligada al hecho de que, hasta la promulgación de la Constitución liberal de 1857, ${ }^{92}$ la parte perdedora podía verse obligada también a pagar las expensas o costas producidas durante el pleito, favoreció que las personas carentes de recursos económicos no pudiesen correr ese riesgo y tuviesen que asumir un papel de meros espectadores durante el litigio, dejando en manos de jueces, fiscales y abogados defensores la resolución del proceso. ${ }^{93}$

\section{Conclusiones}

Como ha sido puesto de manifiesto, tanto los integrantes de las elites médicas y judiciales — jueces, fiscales y abogados-, como los implicados en los delitos tratados - testigos, demandantes y acusados-compartieron la aceptación o, al menos, el conocimiento de un mismo código de valores que permitió el desarrollo de los procesos. Sin embargo, el carácter hermético del lenguaje jurídico marcó una importante línea divisoria entre ambos grupos de actores sociales. La vigencia de las leyes coloniales y el vacío legal producido por la caída en desuso de algunas de las medidas recogidas en las mismas crearon un panorama interpretativo complejo. La actuación de abogados y fiscales fue crucial en la determinación judicial de la culpabilidad y del castigo en cada proceso.

89 De la Pascua, 1835, 396-397.

90 Ibidem, 190.

91 La caída en desuso de la severidad de las penas recogidas supuso que la pena de talión fuese sustituida por la de pago de una indemnización a la parte ofendida.

92 Por el artículo 17 de la Constitución Federal de los Estados Unidos Mexicanos de 1857 las costas judiciales quedaron abolidas.

93 De la Pascua, 1835, 277-279. 
Desde las postrimerías coloniales y durante los primeros cincuenta años de vida independiente, la capital mexicana vivió la confluencia de proyectos encaminados hacia la modernización de las estructuras políticas del país. Estos proyectos convivieron con las reminiscencias de una situación jurídico-legal de origen medieval y con un imaginario conceptual anclado en la teología moral. La ausencia de un conjunto normativo que pusiera fin a esa situación se debió, en parte, a la inestabilidad y la violencia política que asolaron el país a lo largo del periodo estudiado pero también guardó una importante relación con la adecuación de los códigos coloniales a los intereses y a las construcciones de género reinantes entre la elite dirigente.

Por otro lado, a pesar del relajamiento de las condenas en la práctica judicial y de la puesta en libertad de la mayor parte de los detenidos, la aceptación a trámite de las acusaciones, así como el mantenimiento formal de la legislación colonial y de una retórica judicial cargada de constantes alusiones a severidades pasadas supusieron diversos aspectos de una misma violencia simbólica, ${ }^{94}$ un mecanismo de reproducción y consolidación de estructuras de conocimiento que sirvieron como antecedentes en la elaboración, en las décadas siguientes, de la figura del homosexual. Los discursos emanados desde las instancias judiciales operaron de esta manera como mecanismos de difusión, dentro de un universo conceptual basado en la dominación de una masculinidad imperante que logró sentar las bases del sistema sexo/género ${ }^{95}$ actual.

Recibido el 20 de diciembre de 2013 Aceptado el 22 de septiembre de 2014

\section{Bibliografía}

Alfonso X: Las Siete Partidas del Rey Don Alfonso el Sabio. Cotejadas con varios códices antiguos por la Real Academia de la Historia, Madrid, Ediciones Atlas, 1972.

94 Bourdieu, 2000, 11, 12 y 51

95 En atención a la clásica definición dada por Gayle Rubin, un sistema sexo/género está formado por «el conjunto de disposiciones por el que una sociedad transforma la sexualidad biológica en productos de la actividad humana y en el cual se satisfacen esas necesidades humanas transformadas». Rubin, 1986, 37. 
Aquino, Tomás de: Suma de Teología, IV, Biblioteca de autores cristianos, Madrid, 1994.

Barrón Gavito, Miguel Ángel: «El baile de los 41: la representación de lo afeminado en la prensa porfiriana», Historia y Grafía, 34, México, 2010, 47-76.

Bracamonte Allaín, Jorge: «Los nefandos placeres de la carne. La Iglesia y el estado frente a la sodomía en la Nueva España, 1721-1829», Debates en sociología, Departamento de Ciencias Sociales de la Pontificia Universidad Católica del Perú (PUCP), 25-26, Lima, 2001, 393-415.

Buffington, Robert M.: Criminales y ciudadanos en el México Moderno, México, Siglo XXI, 2001.

Bonaventure, Matthieu Joseph: Tratado de Medicina Legal, I, Madrid, Imprenta de D. José María Alonso, 1847.

Bourdieu, Pierre: La dominación masculina, Barcelona, Anagrama, 2000.

Cárdenas Gutiérrez, Salvador: «El delito de prevaricato y la defensa de la honra judicial en el siglo XIX», Anuario Mexicano de Historia del Derecho, 18, México, 2006, 169-182.

De la Pascua, Anastasio: Febrero Mejicano, o sea la Librería de Jueces, abogados y escribanos que, refundida, ordenada bajo nuevo método, adicionada con varios tratados y con el título de Febrero Novísimo dio a luz D. Eugenio de Tapia. Nuevamente adicionada con otros diversos tratados y las disposiciones del Derecho de Indias y del Patrio, por el Lic. Anastasio de la Pascua, I y VII, México, Imprenta de Galván a cargo de Mariano Arévalo, 1835.

De los Reyes, Guillermo: “"Curas, Dones y Sodomitas”: Sexual Moral Discourses and Illicit Sexualities among Priests in Colonial Mexico», Anuario de Estudios Americanos, 67-1, Sevilla, 2010, 53-76.

Escriche, Joaquín: Diccionario razonado de legislación civil, penal, comercial y forense: o sea resumen de leyes, usos, prácticas y costumbres, México, Oficina de Galván, 1876.

Ferrer Muñoz, Manuel: «Pueblos indígenas en México en el siglo XIX: la igualdad jurídica, ¿eficaz sustituto del tutelaje tradicional?», en Molinero Mondragón, Lidia (ed.), La supervivencia del Derecho español en Hispanoamérica durante la época independiente, México, Instituto de Investigaciones Jurídicas, UNAM, 1998, 163-184.

Foucault, Michel: Historia de la sexualidad. La voluntad del saber, Madrid, Siglo XXI, 1998.

Foucautl, Michel: Vigilar y castigar. Nacimiento de la Prisión, Buenos Aires, Siglo XXI, 2003.

Galván Rivera, Mariano: Concilio III Provincial Mexicano, celebrado en México el año de 1585, confirmado en Roma por el papa Sixto V, y mandado observar por el gobierno español en diversas reales órdenes, México, Eugenio Maillefert y Compañía, 1859. 
Garza Carvajal, Federico: Quemando Mariposas. Sodomía e Imperio en Andalucía y México, siglos XVI-XVII, Barcelona, Laertes, 2000.

González, María del Refugio: Historia del Derecho Mexicano, México, UNAM, 1983.

Irwin, Robert McKee: «El Periquillo Sarmiento y sus cuates: el "éxtasis misterioso" del ambiente homosocial en el siglo diecinueve», Literatura Mexicana, IX, 1, México, UNAM, 1998, 23-44.

Irwin, Robert McKee: Mexican Masculinities, Minneapolis, University of Minnesota, 2003.

Irwin, Robert McKee: «"Las inseparables” y la prehistoria del lesbianismo en México», Debate Feminista, 15, XXIX, México, abril 2004, 83-100.

López de Santa Anna, Antonio: «Decreto del gobierno. Ordena que se funden las sentencias en ley, canon, o doctrina», en Dublán, Manuel y Lozano, José María (comps.), Legislación Mexicana, IV, 2201, México, Imprenta del Comercio, 1877.

Monsiváis, Carlos: Los iguales, los semejantes, los (hasta hace un minuto) perfectos desconocidos (A cien años de la Redada de los 41), México, Conaculta, 2001.

Miranda Guerrero, Roberto: «Exploraciones históricas sobre la masculinidad», Revista de Estudios de Género. La ventana, 8, Guadalajara, Universidad de Guadalajara, diciembre 1998, 207-247.

Nepomuceno Rodríguez, Juan: Pandectas hispano-mexicanas o sea código general de las leyes generales, útiles y vivas de las Siete Partidas, México, Librería de J. F. Rosa, 1852.

Novísima Recopilación de las leyes de España. Mandada formar por el Señor D. Carlos IV, IV-V, México, Galván Librero, 1831.

Núñez Becerra, Fernanda, «El agridulce beso de Safo: discursos sobre las lesbianas a fines del siglo XIX mexicano», Historia y Grafía, 31, México, Universidad Iberoamericana, 2008, 49-75.

Ortega Noriega, Sergio: «El discurso teológico de Santo Tomás de Aquino sobre el matrimonio, la familia y los comportamientos sexuales», en Seminario de Historia de las Mentalidades, El placer de pecar y el afán de normar, México, Dirección de Estudios Históricos del Instituto Nacional de Antropología e Historia, INAH, Editorial Joaquín Mortiz, 1988, 77-101.

Ortega Noriega, Sergio: «Los teólogos y la teología novohispana sobre el matrimonio, la familia y los comportamientos sexuales. Del Concilio de Trento al fin de la colonia», en Guzmán Vázquez, Antonio y Martínez O., Lourdes (eds.), Del dicho al hecho... transgresiones y pautas culturales en la Nueva España, México, Seminario de Historia de las Mentalidades, Instituto Nacional de Antropología Social, 1999, 15-38.

Palafox Menegazzi, Alejandra: «Justicia, regulación sexual y feminidad en la ciudad de México (1827-1870)», Trashumante. Revista Americana de Historia 
Social, 2, Medellín/México, Universidad de Antioquía/Universidad Autónoma Metropolitana, 2013, 9-30.

Poder Judicial de la Federación: La Suprema Corte de Justicia. Sus leyes y sus hombres, México, Suprema Corte de Justicia de la Nación, 1985.

Reyes Heroles, Jesús: Liberalismo Mexicano, III, México, Fondo de Cultura Económica, 1974.

Roa Bárcena, Rafael: Manual Razonado de práctica criminal y médico-legal forense mexicana, México, Eugenio Maillefert Editor, 1869.

Rodríguez, Antoine: «El miedo a lo femenino. Estereotipos acerca del homosexual en los discursos institucionales mexicanos, finales del siglo XIX, principios del XX», Amerika [En línea] 4, Madrid, 2011, http://amerika.revues.org/ 1946 [consulta 2 de diciembre de 2013].

Rubin, Gayle: «El tráfico de mujeres: notas sobre la economía política del sexo», Nueva Antropología, 30, México, Universidad Nacional Autónoma de México, 1986, 95-145.

Speckman Guerra, Elisa: Crimen y castigo. Legislación penal, interpretaciones de la criminalidad y administración de justicia (ciudad de México 1872-1910), México, COLMEX/UNAM, 2002.

Speckman Guerra, Elisa: «Justicia, revolución y proceso. Instituciones judiciales en el distrito Federal (1810-1929)», en Mayer, Alicia (coord.), México en tres momentos: 1810-1910-2010. Hacia la conmemoración del Bicentenario de la Independencia y del Centenario de la Revolución Mexicana. Retos y perspectivas, México, Instituto de Investigaciones Históricas, UNAM, 2007.

Suárez, Escobar, Marcela: Sexualidad y norma sobre lo prohibido. La ciudad de México y las postrimerías del Virreinato, México, UNAM, 1994.

Tardieu, Ambrosio: Estudio médico-forense de los atentados contra la honestidad, Madrid, Imprenta médica de Manuel Álvarez, 1863.

Tomás y Valiente, Francisco: Sexo barroco y otras transgresiones premodernas, Madrid, Alianza Editorial, 1990.

Velázquez García, Erik, et. al.: Nueva historia general de México, México, El Colegio de México, 2010.

Weeks, Jeffrey: «La construcción de las identidades genéricas y sexuales. La naturaleza problemática de las identidades», en Szasz, Ivonne y Lerner, Susana (comps.), Sexualidades en México. Algunas aproximaciones desde la perspectiva de las ciencias sociales, México, El Colegio de México, 2005. 